\title{
Factors associated with locoregional recurrence in penile cancer: a case-control study
}

\author{
Factores asociados a recurrencia locoregional en cáncer de pene: un estudio de casos y \\ control
}

\author{
Aldo Zárate-González*, Alejandro Priego-Niño, Victor Salgado-Arroyo, Elieser Fernández-Vivar, and \\ Álvaro Montiel-Jarquín \\ Department of Urology, U.M.A.E. Hospital de Especialidades de Puebla, Centro Médico Nacional. General de división "Manuel Ávila Camacho", \\ Instituto Mexicano del Seguro social, Puebla de Zaragoza, México
}

\begin{abstract}
Purpose: Surgical excision of the primary tumor in penile cancer $(P C)$ has shown good local control with a risk of locoregional recurrence $(L R)$ of $4-8 \%$. The magnitude of such risk and the characteristics that distinguish patients who develop $L R$ from those who do not is controversial. Our goal was to estimate, clinical and oncological characteristics, and outcome of $L R$ in a cohort of patients with PC. Materials and methods: A retrospective, case-control study of ten patients with $L R$ of $P C$ and ten controls. Using a multivariate analysis for clinical and oncological characteristics was evaluated to determine their association with $L R$. Results: Cases and controls were similar in regards to the prevalence of diabetes, age, grade of differentiation, presence of lymphovascular invasion (LVI), and positive margins. In our multiple logistic regression analysis clinical stage (CS), LVI and positive margins were associated with LR. Time to LR had a median of 15 months. Conclusions: Our study confirms that patients with advanced CS, LVI and positive margins after surgical excision of the primary tumor could have higher risk of $L R$. We believe that a close oncological follow-up should be done in patients with adverse oncological characteristics.
\end{abstract}

Key words: Penile. Cancer. Locoregional. Recurrence.

\section{Resúmen}

Objetivo: La escisión quirúrgica del tumor primario en cáncer de pene $(P C)$ ha demostrado un buen control local con un riesgo de recurrencia locorregional $(L R)$ del 4-8\%. La magnitud del riesgo y las características que distinguen a los pacientes con recurrencia locorregional de los que no la presentan son motivo de controversia. Nuestro objetivo fue analizar características clínicas y oncológicas para establecer su relación LR en una cohorte de pacientes con PC. Material y métodos: Estudio retrospectivo de casos y controles de 10 pacientes con $L R$ de PC y 10 controles. Mediante un análisis multivariado se analizaron características clínicas y oncológicas y se determinó su asociación con LR. Resultados: Los casos y controles fueron similares en cuanto a prevalencia de diabetes, edad, grado de diferenciación, invasión linfovascular y márgenes positivos. En nuestro análisis de regresión logística múltiple, el estadio clínico (CS), la invasión linfovascular y los márgenes positivos se asociaron con LR. El tiempo a la LR tuvo una mediana de 15 meses. Conclusiones: Nuestro estudio confirma que los pacientes con CS avanzado, invasión linfovascular y márgenes positivos podrían tener mayor riesgo de $L R$. Creemos que debe realizarse un seguimiento oncológico estrecho en pacientes con características oncológicas adversas.

Palabras clave: Cáncer. Pene. Recurrencia. Locoregional. 


\section{Introduction}

Penile cancer (PC) is a rare neoplasm most common in men aged 50-70 years old'. In 2018, the prevalence in all age males worldwide was 24,974 cases $/ 100,000$, accounting for $0.4-0.6 \%$ of malignant diagnoses in Europe and the USA with a higher incidence in developing countries².

Several risk factors for PC have been identified, including poor hygiene, circumcision status (circumcision in infants or up to adolescence is protective), human papillomavirus infection, phimosis, human immunodeficiency virus infection, smoking, and low socioeconomic status ${ }^{3,4}$.

Pathologically, the vast majority of tumors are classified as squamous cell carcinoma (SCC) of which several subtypes have been recognized, including warty, basaloid, verrucous, papillary, adenosquamous, mixed, and sarcomatoid. Subtypes of PC comprising nonsquamous cell types include basal cell carcinoma, Kaposi sarcoma, leiomyosarcoma, extramammary Paget disease, and melanoma ${ }^{5}$.

The primary site of SCC is the glans penis in $48 \%$ of diagnosed cases; followed by $21 \%$ affecting the prepuce, $9 \%$ involving both glans penis and prepuce, $6 \%$ emerging from the coronal sulcus, and $2 \%$ the shaft ${ }^{6}$. Surgical excision of the primary tumor remains the oncologic gold standard for definitive treatment of the penile primary tumor ${ }^{7}$. This treatment has both shown to result in good local control with a risk of locoregional recurrence (LR) of $4-8 \%{ }^{8}$.

The most important prognostic factor of survival in patients with SCC of the penis is the extent of lymph node metastasis 9 . Approximately $80 \%$ of men with low-stage PC achieve prolonged survival but, as the extent of lymph node metastasis increases, survival decreases precipitously (5-year cancer-specific survival $\mathrm{pN} 0=85-100 \%, \mathrm{pN} 1=79-89 \%$, pN2 $=17-60 \%$, and $\mathrm{pN} 3=0-17 \%)^{10,11}$.

The aim of the present study was to examine our institutional experience for factors associated with LR after the multimodal primary treatment of $\mathrm{PC}$ according to the National Comprehensive Cancer Network (NCCN) guidelines.

\section{Materials and methods}

All cases presenting with LR of PC after the initial treatment and their respective matched controls were selected from a database of 30 patients with histopathology confirmed disease and treated at our third level medical facility from 2012 to 2017.

Surgical management of the primary tumor and regional lymph nodes, as well as treatment with chemotherapy/radiotherapy was performed according to the NCCN guidelines.

Patients were follow-up for at least 2 years after the initial treatment. LR was defined as locoregional disease confirmed by histopathology after the initial treatment.

\section{Statistical methods}

Quantitative variables are presented either as means \pm standard deviation (SD) or as medians with interquartile ranges (IQR), according to their distribution. Data distribution was determined by means of the Shapiro-Wilk's test. Quantitative variables were analyzed using Student's t, Mann-Whitney U, or Wilcoxon tests, whereas for qualitative variables, we used either $\mathrm{c} 2$ or exact Fisher tests. A multivariate, stepwise logistic regression analysis was carried out to explore which clinical and oncological characteristics were associated with LR. Time to LR was calculated from date of primary treatment and was plotted using Kaplan-Meier curve.

\section{Ethics statement}

The present study was reviewed and approved by the institutional review board of Hospital de Especialidades de Puebla, Instituto Mexicano del Seguro Social. Informed consent was not need.

\section{Results}

The analyzed cohort consisted of 20 patients with PC diagnosed, treated, and followed between 2012 and 2017 (mean follow-up was $40 \pm 20$ months). During follow-up, ten patients have LR confirmed by histopathology. The control group consisted of ten patients without evidence of LR.

Table 1 describes the baseline clinical and oncological characteristics of both groups (Table 1). The mean age of the population at diagnosis was $59 \pm 14$ and $69 \pm 11$ years for cases and controls, respectively. The prevalence of diabetes mellitus (cases $57 \%$ vs. controls $42 \% ; p=0.63$ ) was similar among cases and controls. 
Table 1. Baseline characteristics of patients with penile cancer

\begin{tabular}{lccc}
\hline Variable & $\begin{array}{c}\text { Controls } \\
\text { (No recurrence) }^{\mathbf{a}}\end{array}$ & $\begin{array}{c}\text { Cases } \\
\text { (Recurrence) }\end{array}$ & p \\
\hline $\mathrm{n}$ & 10 & 10 & \\
Age (years) \pm SD & $69 \pm 11$ & $59 \pm 14$ & 0.12 \\
\% with diabetes mellitus & 42 & 57 & 0.639 \\
& & & \\
Differentiation \% Grade 1 & 20 & 10 & 0.373 \\
\% Grade 2 & 80 & 90 & \\
\% Lamina propia invasion & 90 & 100 & 0.305 \\
\% Lymphovascular invasion & 40 & 40 & 1 \\
\% Positive margin & 20 & 40 & 0.329 \\
\% Clinical stage I & 20 & 10 & 0.531 \\
II & 50 & 10 & 0.05 \\
III & 20 & 40 & 0.329 \\
IV & 10 & 40 & 0.121 \\
\hline
\end{tabular}

${ }^{\mathrm{a} C o n t r o l}$ group, patients without locoregional recurrence of penile cancer. ${ }^{\mathrm{b}} \mathrm{Cases}$ group, patients with locoregional recurrence of penile cancer. SD: standard deviation.

The proportion of patients showed CS I was (cases $10 \%$ vs. controls $20 \% ; p=0.531$ ), for CS II was (cases $10 \%$ vs. controls $50 \% ; p=0.05$ ), for CS III was (cases $40 \%$ vs. controls 20\%; $p=0.329$ ), and for CS IV was (cases $40 \%$ vs. controls $10 \% ; p=0.121$ ). We find statistically significant difference only for CS II.

All cases of the analyzed cohort presented SCC. The differentiation grade of the primary tumor was Grade 1 in $20 \%$ and Grade 2 in $80 \%$ of the patients in the control group; while in the case group it was $10 \%$ and $90 \%$, respectively $(p=0.373)$.

The presence of invasion of the lamina propria in the primary tumor was present in $90 \%$ of patients in the control group and in all of patients in the case group $(p=0.305)$. While the presence of lymphovascular invasion (LVI) was $40 \%$ in both groups $(p=1)$.

After surgical excision of the primary tumor, positive margins were found in $40 \%$ of cases and $20 \%$ of controls $(p=0.329)$. The time to LR in our study had a median of 15 months (IQR 12-18) (Fig. 1).

In a multiple logistic regression analysis that included age and oncologic characteristics, CS, LVI, and positive margins were associated with LR; however, CS was the only variable that showed a statistically significant difference (Table 2).

\section{Discussion}

Although cancer of the penis is a rare genitourinary malignancy, it frequently poses a clinical management dilemma for the urologist. Such dilemmas can arise due to delays in clinical presentation, diagnostic error, and ambiguous strategies for treatment, in terms of

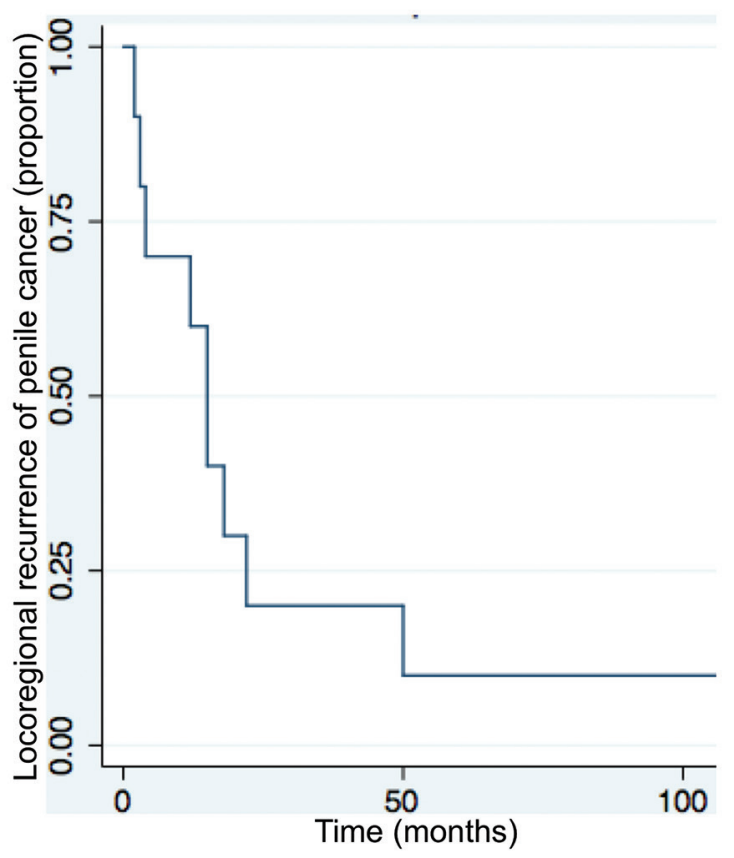

Figure 1. Kaplan-Meier estimates of time to locoregional recurrence in the patients included with penile cancer.

efficacy versus morbidity ${ }^{10}$. Notwithstanding therapeutic intent, prognosis is largely dictated by the pathological stage of the disease, including the extent of lymph node metastasis, coupled with the histological features of the primary tumour ${ }^{11}$.

Surgery is central to the management of $P C$, having pivotal roles in diagnosis and staging of the primary tumor. Intervention has evolved from conventional surgical amputation (that is, partial or total penectomy) to organ preserving surgery. Today, a range of minimally invasive therapeutic options, including topical treatments, laser ablation, and modified local excision have been developed. Emerging opinion suggests that organ preserving treatment offer the opportunity for disease control and should be sought when oncologically feasible to retain quality of life and maximize sexual function ${ }^{10,12}$.

Largest series of patients with PC have shown that while after a partial penectomy, the risk of $L R$ is $4-5 \%$, organ preservation strategies have local recurrence rate of $13.7 \%$. However, long-term survival does not appear to be compromised by local recurrence since most cases are still surgically salvageable ${ }^{8,12,13}$. Previously, it has been illustrated in other series that LVI, presence of high grade and Stage T2 or greater predicted the occurrence of LR in a series on penile-preserving treatment ${ }^{14}$. Our data support this 
Table 2. Multiple logistic regression analysis for risk factors associated with locoregional recurrence in penile cancer

\begin{tabular}{lccc}
\hline Variable & OR & Cl 95\% & p \\
\hline Age & 0.832 & $(0.6891 .005)$ & 0.056 \\
Differentiation grade ${ }^{\mathrm{a}}$ & 0.239 & $(0.00134 .741)$ & 0.574 \\
Lymphovascular invasion & 3.238 & $(0.11590 .902)$ & 0.490 \\
Positive margin & 2.559 & $(0.015434 .665)$ & 0.720 \\
Clinical stage & 4.244 & $(1.06916 .842)$ & 0.04 \\
\hline Tumor differentiation grade. & & &
\end{tabular}

conclusion. In addition, we identified the presence of a positive margin as risk factor for LR, without reaching statistical significance. This shows that perioperative frozen section assessment can be of significant value, especially in cases suspicious for tumor involvement at the excision margins ${ }^{15}$.

In a retrospective study, Albersen et al. identified four risk factors for LR in a univariate model: perineural invasion, carcinoma in situ, positive margins on definitive pathology, and the presence of highgrade SCC. None of these risk factors was a significant predictor of LR in multivariate cox regression ${ }^{16}$. These findings contrast with our results.

We have identified three risk factors for $L R$ in a multiple logistic regression model: CS, LVI and positive margins. However, CS was the only variable that showed a statistically significant difference, which may likely be attributed to a low number of events in this cohort. Other series have identified 1 single risk factor to be significant for LR. However, we believe additional emerging predictive factors which now do not reach statistical significance may be of equal importance ${ }^{13,16}$.

In the previous series, $66 \%$ of all LR occur within 2 years ${ }^{16}$, this finding is consistent with our results. The time to LR in the present study had a median of 15 months (IQR 12-18) so we believe that a close oncological follow-up should be done in the $1^{\text {st }}$ months after the treatment in patients with adverse oncological characteristics.

In this cohort, the age at diagnosis of PC coincides with previous studies with a peak during the sixth decade. In relation to this, it is interesting to note that patients in our cases group were younger that patients in the control group, but without reaching statistical significance. During the review of clinical records, no data were found about the time elapsed between the appearance of the first symptom and clinical diagnosis. Perhaps other important factors also have a role and were overlooked.

We consider that studies with a longer follow-up and with a larger number of patients are needed to determine the association of clinical and oncological characteristics, with LR.

\section{Conclusions}

Our study confirms that patients with advanced CS, LVI and positive margins after surgical excision of the primary tumor could have higher risk for LR.

Our findings should to be considered with caution in view of the inherent limitations of the study, namely, its retrospective nature and the low number of evaluated subjects. Undoubtedly, larger scale, prospective studies are needed to determine the magnitude of risk.

\section{Conflicts of interest}

The authors have no potential conflicts of interest to disclose.

\section{Ethical disclosures}

Protection of human and animal subjects. The authors declare that no experiments were performed on humans or animals for this study.

Confidentiality of data. The authors declare that they have followed the protocols of their work center on the publication of patient data.

Right to privacy and informed consent. The authors declare that no patient data appear in this article.

\section{References}

1. Barnholtz-Sloan JS, Maldonado JL, Pow-sang J, Guiliano AR. Incidence trends in primary malignant penile cancer. Urol Oncol Semin Orig Investig. 2007;25:361-7.

2. Heller DS. Lesions and neoplasms of the penis: a review. J Low Genit Tract Dis. 2016;20:107-11.

3. Diorio GJ, Leone AR, Spiess PE. Management of penile cancer. Urology. 2016;96:15-21.

4. Larke NL, Thomas SL, Dos Santos Silva I, Weiss HA. Male circumcision and penile cancer: a systematic review and meta-analysis. Cancer Causes Control. 2011;22:1097-110.

5. Downes MR. Review of in situ and invasive penile squamous cell carcinoma and associated non-neoplastic dermatological conditions. J Clin Pathol. 2015;68:333-40.

6. Mosconi AM, Roila F, Gatta G, Theodore C. Cancer of the penis. Crit Rev Oncol Hematol. 2005;53:165-77.

7. McDougal WS, Kirchner FK Jr., Edwards RH, Killion LT. Treatment of carcinoma of the penis: the case for primary lymphadenectomy. J Urol. 1986;136:38-41.

8. Leijte JA, Kirrander P, Antonini N, Windahl T, Horenblas S. Recurrence patterns of squamous cell carcinoma of the penis: recommendations for follow-up based on a two-centre analysis of 700 patients. Eur Urol. 2008;54:161-8. 
9. Srinivas V, Morse MJ, Herr HW, Sogani PC, Whitmore WF Jr. Penile cancer: relation of extent of nodal metastasis to survival. J Urol. 1987;137:880-2.

10. Hakenberg OW, Compérat EM, Minhas S, Necchi A, Protzel C, Watkin N. EAU guidelines on penile cancer: 2014 update. Eur Urol. 2015;67: 142-50.

11. Slaton JW, Morgenstern N, Levy DA, Santos MW Jr., Tamboli P, Ro JY, et al. Tumor stage, vascular invasion and the percentage of poorly differentiated cancer: independent prognosticators for inguinal lymph node metastasis in penile squamous cancer. J Urol. 2001;165: 1138-42.

12. Burnett AL. Penile preserving and reconstructive surgery in the management of penile cancer. Nat Rev Urol. 2016;13:249-57.
13. Djajadiningrat RS, van Werkhoven E, Meinhardt W, van Rhijn BW, Bex A van der Poel HG, et al. Penile sparing surgery for penile cancer-does it affect survival? J Urol. 2014;192:120-5.

14. Philippou $P$, Shabbir M, Malone $P$, Nigam R, Muneer A, Ralph DJ, et al. Conservative surgery for squamous cell carcinoma of the penis: resection margins and long-term oncological control. J Urol. 2012;188:803-8.

15. Minhas S, Kayes O, Hegarty P, Kumar P, Freeman A, Ralph D. What surgical resection margins are required to achieve oncological control in men with primary penile cancer? BJU Int. 2005;96:1040-3.

16. Albersen M, Parnham A, Joniau S, Sahdev V, Christodoulidou M, Castiglione $\mathrm{F}$, et al. Predictive factors for local recurrence after glansectomy and neoglans reconstruction for penile squamous cell carcinoma. Urol Oncol. 2018;36:141-6. 